\title{
ESTETIKA (DALAM) DESAIN
}

\author{
FX Widyatmoko \\ Dosen Program Studi Disain Komunikasi Visual \\ Jurusan Disain FSR ISI Yogyakarta \\ Email: koskowbuku@gmail.com
}

\begin{abstract}
Aesthetics is a word that is often present in the areas of art, including fine art. However, in the area of visual communication design aesthetic rarely spoken words compared with the area of fine arts (fine arts). Not that there are no problems in the design aesthetic. Aesthetic issue still exists, but it is rarely used as a design concept design. Even the design of the study area, there are aesthetic studies. However, the study could have imagined aesthetic has a great distance to the aesthetics of everyday design. There is also an effort to facilitate the understanding of aesthetics is to provide the name of a visual strategy (Andry Masri, Jalasutra, 2010). However, the strategy also has not explained the visual aesthetic studies are very diverse. The phrase is intended to facilitate common aesthetic learned, particularly for the needs of design planning (especially product design).

This paper aims to offer a way to understand the aesthetic rather than through understanding, but to find the position of each design aesthetic in visual communication design. The objects that were examined in the two final ISI Visual Communication Design (one object assessment, the object creation), as well as a book cover design. The goal is clear, to give an overview of the aesthetic. Hopefully, the growing diversity of aesthetic closer to the day-to-day. In short, bringing together academic research, design work, the aesthetic experience everyday.
\end{abstract}

Keywords: Aesthetics, status, context

\section{Pengantar}

Tulisan ini berusaha memberi tawaran cara (strategi) dalam memahami estetika dalam desain komunikasi visual. Cara berangkat yang dipilih yaitu tidak memulai dari pertanyaan apa estetika, namun di mana estetika berada. Maka itu, keragaman karya desain jadi sangat strategis guna menghasilkan pengetahuan tentang bagaimana estetika diterapkan.

Di lain sisi tulisan ini juga prihatin manakala menjumpai berbagai Tugas Akhir Desain Komunikasi Visual, sejauh yang penulis jumpai, jarang atau bahkan nyaris tidak menuliskan konsep estetika dalam perancanganperancangan tersebut. Kalaupun di sana terdapat konsep umumnya konsep kreatif dan konsep media. Padahal, dalam hal tertentu, konsep estetika berbeda dari konsep media atau kreatif. Estetika dalam ruang ini tidak sekedar berurusan dengan yang tampak, namun juga berurusan dengan wacana.

\section{Berangkat Dari Praktik}

Estetika merupakan sebuah kata yang tidak mudah dijelaskan. Namun, estetika itu sendiri kerap jadi alasan cara mengalami atau menghadapi sebuah karya seni. Indah, bagus, fantastis, merupakan beberapa kata sebagai menjelaskan hadirnya dimensi estetika dalam mengalami perjumpaan dengan suatu karya seni. Di lain pihak, indah, bagus, fantastis, atau estetis itu sendiri tidak mudah dijelaskan. Dalam tulisan ini persoalan seperti tidak mudah dijelaskan akan dihindari. Justru tulisan ini memilih menjelaskan estetika, bukan apa, namun di mana kedudukannya dalam sebuah karya desain komunikasi visual.

"Berangkat dari praktik" juga mau menyampaikan bahwa tiap karya mengandung nilai estetika. Hal tersebut dilandasi pemikiran bahwa estetika tidak sebatas yang tampak, namun juga yang tidak tampak (wacana). Maka itu, estetika sebaiknya tidak sebatas dipahami sebagai bentuk-bentuk yang indah, harmoni, tertata, rapih, 
dsb. Estetika perlu dicari yang berada di luar bentuk-bentuk tersebut. Namun demikian hadirnya pengelolaan bentuk-bentuk tadi menjelaskan bahwa di sana telah hadir peran estetika yaitu pada soal materialitas bentuk seperti unsur/elemen misalkan warna, tekstur, ukuran, bidang, dsb. Metrialitas inilah yang perannya sama-sama sebagai perangkat (-perangkat) yang mencirikannya sebagai karya visual.

Selain itu desain juga memiliki kebenaran pada konteks masing-masing. Dalam kalimat singkat sebuah desain yang berhasil di suatu tempat belum berhasil untuk tempat lain. Kondisi ini melahirkan kesadaran bahwa estetika sebuah desain tidak bisa lebih tinggi dibanding estetika desain di tempat lain. Pemaksaan suatu konsep estetika hanya melahirkan wacana dominan. Namun sejarah mencatat bahwa peran-peran dominasi estetika juga berlangsung. Inilah yang dapat menjelaskan bahwa estetika tidak berhenti sebatas form dan content, namun form dan context. Dominasi itu sendiri menjelaskan hadirnya wacana lain dalam estetika yaitu kekuasaan, bisa karena pasar, ideologi, dsb. Sejarah pula mencatat bahwa Marxisme memiliki konsep estetika yang berbeda dari borjuasi, pula modern berbeda konsep estetika dengan tradisi.

Pengantar di atas sebatas mau menyampaikan bahwa tulisan ini bekepentingan mencari kedudukan estetika dalam sebuah desain (where), bukan memulai lewat pernyataan definitif (what). Ini bukan berarti tidak ada teori-teori estetika yang tidak digunakan. Justru sebaliknya, teori-teori tersebut sebenarnya melatari praktik sebuah rancangan desain, yang terlupa yaitu konsep estetika. Persis di sini bendel-bendel Tugas Akhir memperlihatkan bolong (bukan absen) suatu pengetahuan khas seni, yaitu estetika.Lebih jelasnya berikut ini akan diuraikan pencarian di mana estetika berada dalam sebuah karya desain. Maka itu pendekatan yang digunakan ialah kasuistik. Sebagai kasusistik tulisan ini tidak lengkap dalam memberi pengetahuan estetika tersebut. Di sinilah batasan dari tulisan ini. Artinya, masih terbuka kemungkinan dilakukan kajian estetik berikutnya, minimal pada kasuskasus desain yang lain.

\section{Perancangan Typeface "Nusantara": identitas budaya diantara bentuk-fungsi dan bentuk-makna}

Typeface "Nusantara"adalah Tugas Akhir Prima Ditya Laksanrancang berusaha mengakomodir dua kepentingan, yaitu prinsip tipografi modern dan bentuk-bentuk wayang. Typeface ini diranacang hingga mencapai fungsi sebagai huruf baca (body text). Persoalan yang muncul yaitu bagaimana mempertemukan prinsip dan bentuk huruf Latin dengan bentuk-bentuk pada wayang kulit. Sebagai huruf baca pun typeface tersebut tidak dapat lepas dari prinsip dasar dan ergonomi huruf yaitu kejelasan bentuk dan keterbacaan.

Sebagai usaha menghadirkan bentukbentuk (simbolisasi) wayang kulit, huruf pun tak lepas dari kesan "menghias". Hal tersebut setidaknya menggambarkan persoalan estetik dalam perancangan typeface, yaitu mempertemukan fungsi dan simbol. Jika ditempatkan dalam mazhab esetika maka kedudukannya berada diantara form follows function dan form follows meaning. Secara kebentukan meaning, bentuk-bentuk simbolisasi pun mengalami reduksi. Secara fungsi sebagai huruf baca, bentuk pun harus memuat ikon/simbol yang dipilih dari bentuk wayang kulit.

Jika diamati hasil rancangan typeface "Nusantara" di sana terlihat bahwa meski huruf ini masih dapat dibaca dalam ukuran 8 poin, namun ia kurang ergonomis untuk body text panjang seperti pada surat kabar, majalah, atau buku. Paling banter dapat diterapkan pada teks baca yang tidak panjang seperti undangan pernikahan, atau untuk quote text, dsb. Keterbatasan tersebut tidak berarti sebagai huruf baca typeface "Nusantara" tidak memiliki nilai estetik. Sebaliknya, keterbatasan tersebut menyampaikan keberadaan estetika yaitu negosiasi antara form follows function dan form follows meaning.

Jika ditempatkan ke dalam wacana, persoalan estetika pun mencapai pada persoalan tentang identitas, yaitu antara yang global (latin) dan yang lokal (nusantara). Pada soal identitas itulah estetika menduduki persan sebagai wacana, 


\section{ABCDEFGHIJKLMn APQRSTUUUKYZ abcdefghijhlmnopq rstuvuxyz 1234567890

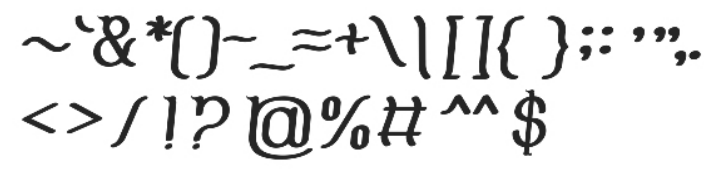

Keterangan: Typeface "Nusantara” versi reguler. (Sumber: Tugas akhir Prima Ditya, 2012)
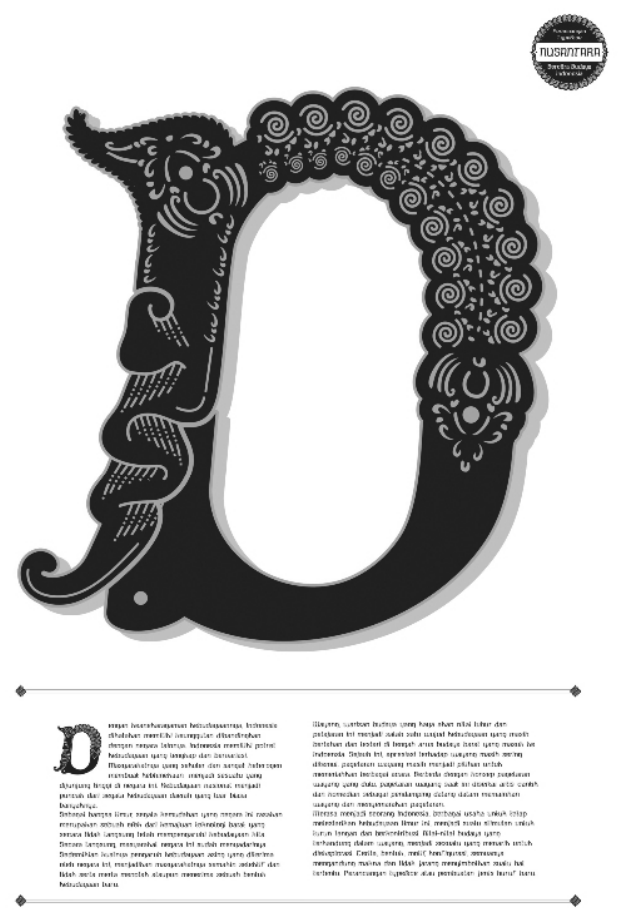

Gambar 1. Typeface "Nusantara" versi dropcap huruf D. Kesan ornamentik terasa pada huruf dropcap, dan di sini dapat disampaikan bahwa form follows meaning lebih dominan dibandingkan dengan form follows function. (Sumber: Tugas akhir Prima Ditya, 2012)

yaitu pertisipasi (jika tidak mau disebut sebagai aksentuasi) yang lokal pada yang global. Partisipasi jadi penting manakala selama ini tipografi didominasi huruf latin, meski dalam wacana global maupun sehari-hari (setidaknya di Indonesia) huruf latin merupakan perangkat aksara yang kerap digunakan.

Konsep partisipasi tadi menjelaskan bahwa bukan penghapusan dominasi yang jadi tujuan, namun usaha untuk memberi kesempatan bagi yang lokal. Disamping itu dengan cara demikian budaya lokal secara tidak langsung dilestarikan, yaitu dengan cara meleburkan diri dalam budaya global (aksara latin). Singkat kata bolehlah disampaikan bahwa estetika yang ada yaitu estetika yang negosiatif.

Kritik estetik yang dapat diajukan untuk typeface "Nusantara" yaitu di sana masih berdiri dominasi Jawa untuk merepresentasikan Nusantara. Artinya, huruf tersebut jika dihadapkan kepada subyek lain di luar Jawa, belum tentu ia merupakan satu-satunya typeface yang dapat mewakili keragaman budaya Nusantara itu sendiri. Tidak stabilnya identitas tersebut juga dapat ditemukan pada penanda bentuk wayang pada huruf. Tingkat reduksi bentuk wayang sedemikian rupa tersebut juga dapat mengatakan bahwa typeface "Nusantara" sekaligus bukan penanda akan Nusantara. Hal ini dapat dilihat pada perbandingan antara huruf dengan drop cap, bahwa pada huruf (baik seri reguler, italic, bold, bold italic) akan berbeda jauh dari bentuk huruf drop cap yang secara tidak langsung kembali kepada kecenderungan ornamentik dan menjadikannya sangat kuat dengan bentuk-bentuk yang terdapat pada wayang kulit Purwa (Jawa).

\section{Kemasan Wingko Babat Semarang: pengalaman menjadi modern di kota}

“...Merek-merek Wingko Babat ini hanya bisa berbicara lebih baik dengan memperhatikan kembali hubungan-hubungan di bawah permukaan melalui sudut pandang baru, yang tidak lagi peduli kepada 'indah tak indah', bukan bagaimana kebudayaan terpajang sebagai bendabenda, melainkan kepada bagaimana kebudayaan itu berlangsung." (Ajidarma, dalam Afnita, 
2009:65)

Ulasan tentang kemasan Wingko Babat Semarang ini merujuk pada Tugas Akhir Pangkajian Natalia Afnita, DKV ISI Yogyakarta, 2010. Namun, dalam penelitian ini belum dijelaskan tentang estetika. Penelitian tersebut mengkaji kemoderenan dalam desain-desain kemasan Wingko Babat Semarang. Metode penelitian lapangan juga diterapkan oleh Natalia terutama dalam urusan pendekatan konstruksi sosial yaitu pada persoalan data riil budaya dagang Wingko Babat (termasuk praktik desain kemasannya).

Dalam temuannya Natalia mengkategorikan tiga kategori kemasan Wingko Babat berdasarkan gambar etiketnya, yaitu (1) yang memilih gambar moda transportasi termodern, (2) moda transportasi paling tua, (3) dan yang di luar kedua kategori tersebut. Ketiganya menggambarkan kontestasi persaingan pasar, salah satunya yaitu untuk berlomba-lomba merepresentasikan diri sebagai yang asli.

Mencari kedudukan estetika dalam desain-desain kemasan Wingko Babat Semarang perlu menghubungkan desain kemasan dengan asal-usul dan sejarah (modern) Kota Semarang. Wingko Babat Cap Kereta Api merupakan pionir makanan oleh-oleh tersebut. Merek tersebut diciptakan oleh D. Mulyono (The Ek Tjong) bersama istrinya Loe Lan Hwa, dimana orang tua istri D. Mulyono, Loe Soe Siang, merupakan

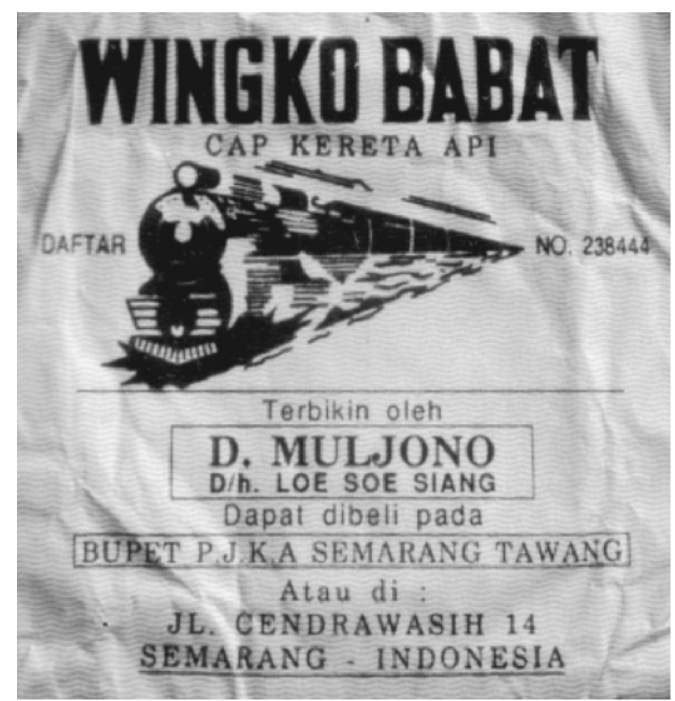

pembuat Wingko Babat di kota Babad (Jawa Timur). Waktu itu D. Mulyono juga bekerja di kereta api jurusan Semarang-Surabaya. Tidak semua orang dapat bekerja di kereta api, yang dapat bekerja yaitu orang Belanda, lalu Tionghoa, dan berikutnya pribumi, itu pun kecil kemungkinannya bagi pribumi untuk dapat bekerja di kereta api. Peraturan tersebut merupakan politik Belanda yang juga diterapkan ke dalam tata kota dimana di sebuah kota terdapat perkampungan berbagai macam etnis, biasanya terdapat tiga wilayah yaitu untuk orang Belanda, untuk Timur Asing (Tionghoa, India, Arab), dan untuk pribumi. Selain menciptakan partisi-partisi tersebut Belanda juga membangun benteng di sekitar pusat pemerintahan.

"Ciri penting lain kota kolonial adalah lokasinya di dekat laut atau sungai, karena para pendatang Eropa yang merupakan penghuni dari kota-kota tersebut memerlukan kemudahan agar kapal-kapal mereka dapat mengekspor produk dari daerah bersangkutan, serta dapat mengimpor produk dari Eropa. (Purnawan Basundoro, 2012, halaman 85$) \ldots$ Penduduk kota dibuat berlapislapis berdasarkan latar belakang etnis. Lapisan pertama adalah orang-orang Belanda dan Eropa lainnya, lapisan kedua adalah dari bangsa Timur Asing (Cina, Arab, India, Jepang, dan lain-lain), dan lapisan ketiga adalah orang-orang bumiputra." (Basundoro, 2012:94-95)

Semarang merupakan kota modern bentukan
Gambar 2. Pionir kemasan Wingko Babat Semarang "Cap Kereta Api", tahun pembuatan 1958, bahan kertas, teknik cetak offset. Desain tersebut bukan desain versi awal, namun sudah dikembangkan. (Sumber: Natalia Afnita, 2010) 
kolonial. Ciri-ciri kota kolonial antara lain dekat dengan sungai atau laut. Kedekatan tersebut guna memenuhi kebutuhan barang keluar masuk (ekspor, impor). Selain terdapat pelabuhan, di Semarang juga terdapat stasiun kereta api, dan di stasiun kereta api di Semarang merupakan stasiun yang pertama kali dibangun oleh Belanda di Indonesia (Hindia Belanda). Kota pertama yang dibangun Belanda yaitu Batavia, kota metropolitan pertama yaitu Surabaya. Letak Semarang berada di pelintasan jalur BataviaSurabaya. Maka dapat dibayangkan kesibukan kota Semarang yaitu sebagai kota pelintasan dagang, baik melalui kereta maupun kapal laut. Ringkasnya, Kota Semarang, kereta api, dan objek lain ciptaan Belanda (sekolah) merupakan bukti modernisasi telah hadir di Hindia Belanda.

Pada 1882, Komisi dari Indisch Genootschap menyatakan tentang keunggulan dari hadirnya kereta api di Hindia: "kereta api dan rel-rel kereta kecil, yakni trem-trem di Hindia Belanda, terbukti merupakan yang paling bermanfaat dari temuan-temuan sekarang ini, kemenangan paling mengagumkan oleh manusia atas waktu dan jarak, insentif paling kuat untuk bekerja keras, pertukaran nilai-nilai dan peradaban."(Afnita, 2010:44)

Semarang juga dinamai sebagai the little Netherland, dan sebagai pusatnya yaitu kawasan yang kini dinamai Kota Lama. Jika di kawasan Kota Lama banyak berdiri bangunan pemerintahan, maka di kawasan yang kini bernama Jalan Pemuda merupakan kawasan presentasi gaya hidup. Stasiun kereta api di Semarang berada di kawasan Kota Lama tersebut, dan Jalan Pemuda merupakan perpanjangan dari arah Kota Lama menuju ke arah Timur dan jaraknya tidak jauh.

"Modernisasi kota-kota itulah yang pada akhirnya memancing proses migrasi yang lebih besar. Orang-orang dari desa berbondong-bondong datang ke kota untuk mencari penghidupan baru yang lebih menjanjikan sekaligus menikmati kota yang telah melahirkan imajinasi-imajinasi baru bagi kaum pendatang." (Basundoro, 2012:123)

Pada awalnya desain-desain kemasan Wingko
Babat banyak yang menampilkan gambar kereta api (termodern) itu karena kereta api dan pusat kota (ruang estetisasi gaya hidup) masih di kawasan yang sama. Dalam perjalannya, setelah kemerdekaan RI, kawasan pusat kota bergeser ke arah timur Jalan Pemuda yaitu Kawasan sekitar Tugu Muda. Pergeseran orientasi pusat kota tersebut ditandai lewat kian majunya moda transportasi antara lain bus, kapal, pesawat, dimana objek-objek tersebut juga dijadikan pilihan gambar kemasan Wingko Babat di kemudian hari. Selain terjadinya pergeseran pusat kota, keragaman gambar desain kemasan juga disebabkan somasi yang dilakukan oleh produsen Cap Kereta Api.

"Pembangunan Tugu Muda di tahun 1952 serta pembangunan kawasan Simpang Lima tahun 1965, mengubah posisi sentral perdagangan di Semarang yang dulunya terletak di Kawasan Kota Lama, Pecinan, dan Alun-alun di depan Masjid Kauman (kini menjadi Pasar Johar). Jalan Pandanaran, yang terletak diantara Tugu muda dan kawasan Simpang Lima, mulai ramai dipadati pedagang kaki lima sejak dibangunnya pertokoan oleh-oleh seperti Bandeng Juwana pada dekade 1980an. Sejak itulah pedagang keliling wingko babat mulai menetap, dengan membuka kios kecil di sepanjang trotoar depan pertokoan tersebut. “ (Afnita, 2010:33)

Dalam perkembangannya desain kemasan Wingko Babat tidak menerapkan objek moda transportasi sebagai cara ngomong paling modern. Kemoderenan pun dimaknai sebagai yang tertua (gambar kereta api tertua), juga yang bukan merujuk objek moda transportasi seperti Cap Mangga Dua (karena yang memiliki pernah bekerja di Mangga Dua Jakarta), Cap Cakra (karena yang memiliki suka wayang Prabu Kresna dimana cakra merupakan senjata milik Kresna, dsb). Terdapat pula Wingko Babat merek Dyriana yang menerapkan kertas khusus untuk kemasan Wingko Babat (kedap air dan udara), dikarenakan yang memiliki merek tersebut adalah seorang dokter. 

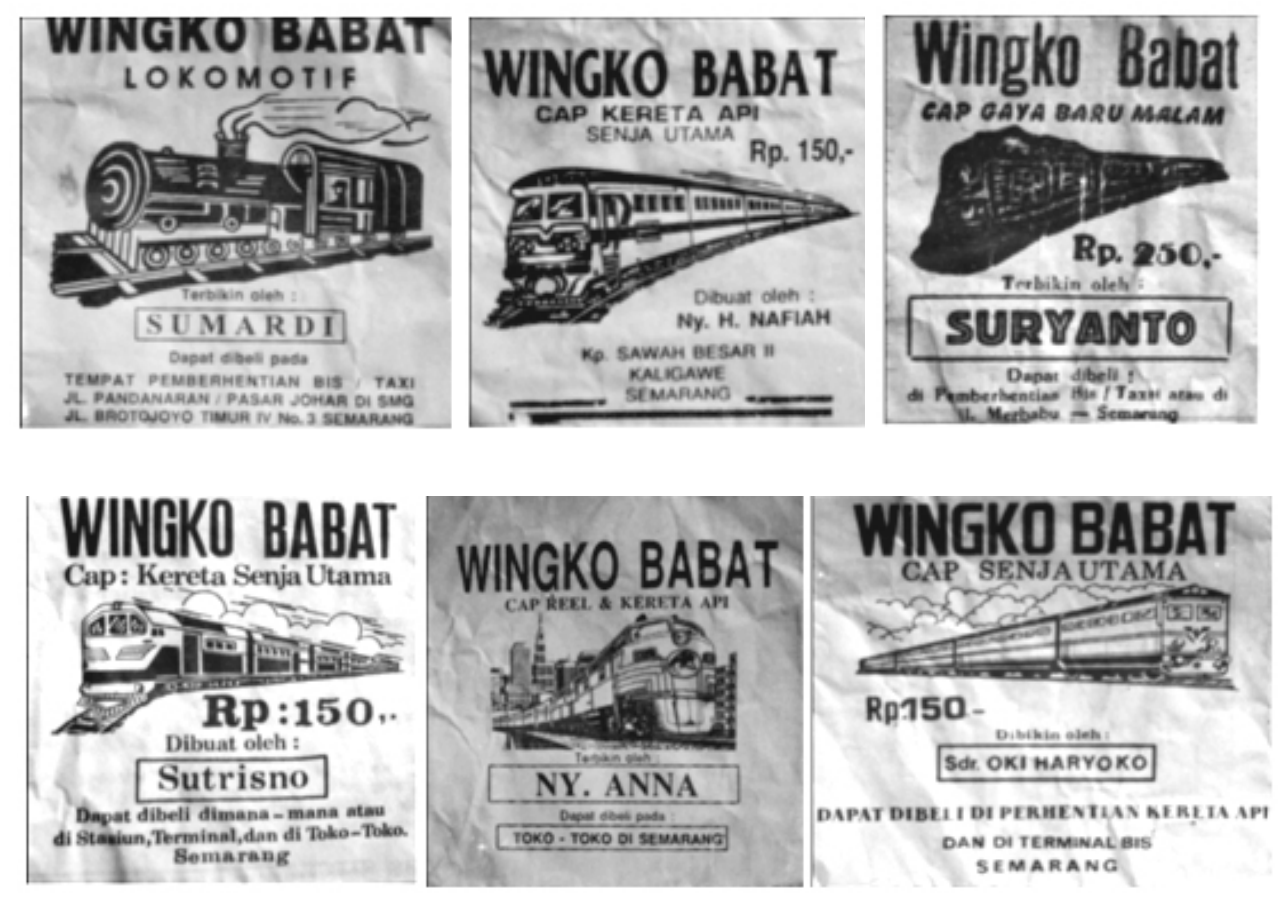

Gambar 3. Merek-merek kemasan Wingko Babat bernuansa kereta api.

(Sumber: Afnita, 2010:102)
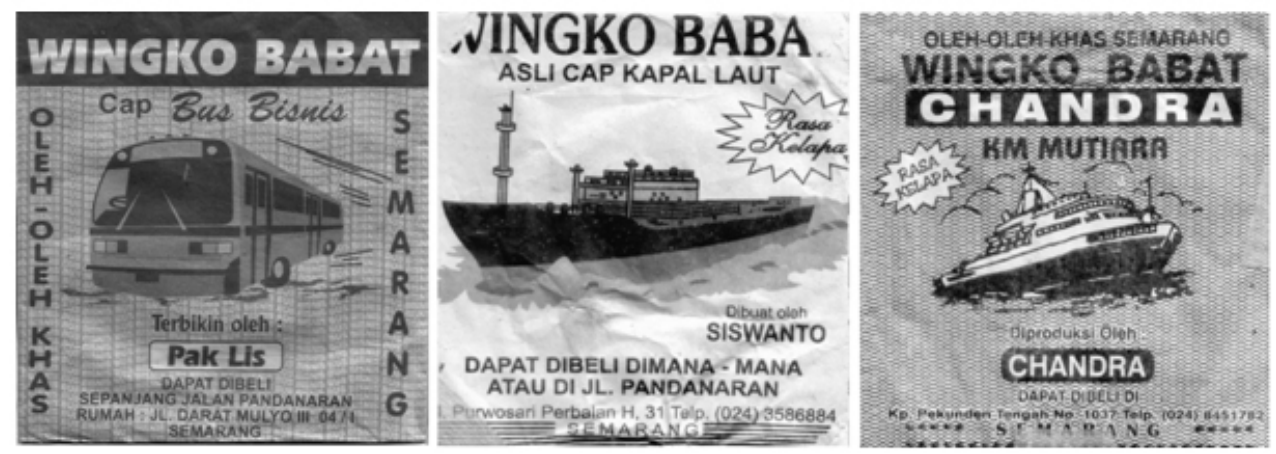

Gambar 4. Merek-merek kemasan Wingko Babat bernuansa bus, kapal laut..

(Sumber: Afnita, 2010:126)
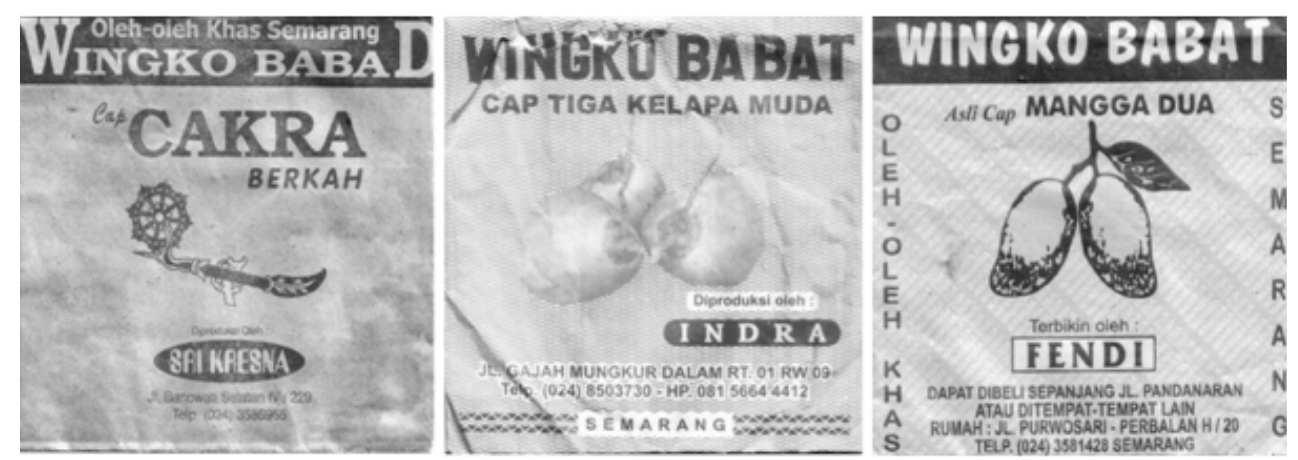

Gambar 5. Merek-merek kemasan Wingko Babat merek Cakra, Kelapa Muda, dan Mangga Dua. (Sumber: Afnita, 2010:122, 128) 


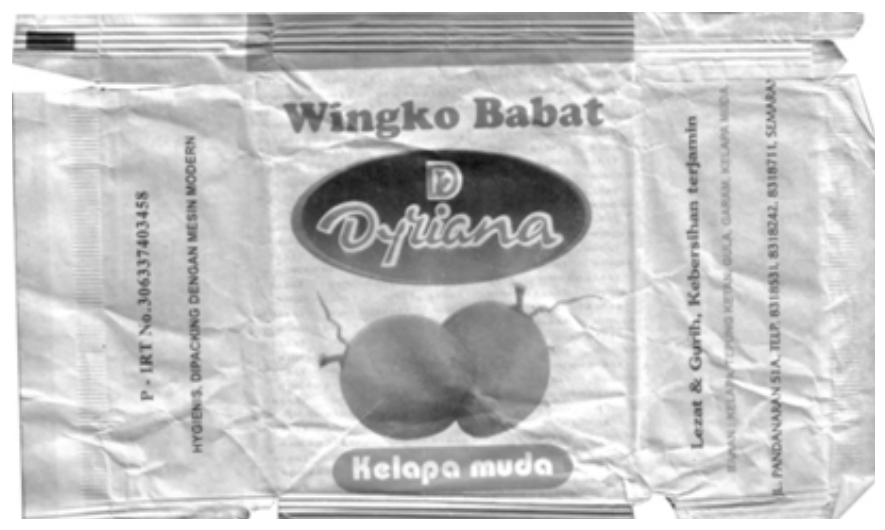

Gambar 6. Wingko Babat merek Dyriana yang dikemas dengan mesin modern, menggunakan kertas khusus untuk makanan (kedap udara dan air, dan makanan jadi awet untuk beberapa hari, karena Wingko Babat terbuat dari kelapa dan mudah basi dalam beberapa hari). (Sumber: Afnita, 2010:132)

Ringkasnya, mencari kedudukan estetika dalam desain-desain kemasan Wingko Babat Semarang tak lepas dari pengalaman masyarakat (Kota Semarang) akan kemoderenan. Bergesernya pusat kota, termasuk pusat hiburan/konsumsi/gaya hidup, juga ditandai dengan bergesernya gambargambar desain kemasan Wingko Babat. Pengalaman akan kemoderenan itulah yang tercermin dalam gambar-gambar berbagai desain kemasan Wingko Babat Semarang.

"Fenomena ini menarik untuk diamati, mengingat sejauh apapun para kompetitor berusaha menampilkan produknya, baik identik atau berusaha berbeda, tetap saja masih terdapat sisa-sisa 'penghormatan' pada desain kemasan produk pertama Wingko Babat" (Afnita, 2010:70)

Kasus kemasan Wingko Babat Semarang tidak sepenuhnya dapat menjelaskan kontestasi kemasan makanan di kota lain, misalkan Bakpia Pathuk Jogja. Pada Bakpia Pathuk boleh jadi yang berlaku ialah kode penomoran/angka, dan tidak terdapat keterkaitan dengan kemoderenan dalam artian menunjuk pada objek-objek modernitas (moda transportasi, bangunan, dsb), namun memiliki keterkaitan dengan feng shui (keyakinan). Sedangkan pada kemasan-kemasan Wingko Babat Semarang kode yang beroperasi ialah moda transportasi modern, meski dalam perjalanannya ia mengalami perubahan kode gambar, namun tetap tidak beranjak jauh dari modernitas dan pergeseran pusat kota. Meski demikian, baik kemasan Wingko Babat maupun Bakpia Pathuk menggambarkan bahwa di sana terdapat pengkodean yaitu merujuk pada asal-usul (yang pertama). Dalam bahasa Natalia dituliskan "penghormatan", namun dapat pula kode menjelaskan tingkat sugesti konsumen. Sugesti ini hadir karena selama ini kemasan dikodekan sehingga menjadi sintaks suatu desain. Pada kemasan Wingko Babat Semarang semantikanya menunjuk pada kemoderenan, meski beberapa memiliki semantika lain yaitu subyek (Mangga Dua, Cakra, Dyriana). Perubahan semantika tersebut, atau secara luas tentang estetika desain, juga dikarenakan politik yaitu somasi yang dilakukan oleh produsen Wingko Babat Cap Kereta Api. Maka itu, perubahan "yang estetis" di sini juga dapat dijelaskan karena terdapat peristiwa "yang politis"(somasi).

\section{Sampul Buku "Pesona 'Barat"': pengalaman di antara yang etnis dan yang eksotisme}

Kasus lain tentang estetika yaitu sampul buku "Pesona 'Barat': Analisa Kritis-Historis tentang Kesadaran Warna Kulit di Indonesia“. Buku ini ditulis oleh Vissia Ita Yulianto, diterbitkan oleh penerbit Jalasutra, 2007. Secara garis besar buku ini mengulas wacana/narasi identitas warna kulit perempuan Indonesia (dulu disebut Hindia Belanda, secara tegas diistilahkan dengan inlander sebagai kontruksi Barat (sang orientalis) dalam memandang rendah kaum pribumi/ Timur, termasuk perempuannya). Pendekatan yang digunakan yaitu sejarah, karena itu, mitos-mitos tentang citra perempuan yang dibahas dalam buku ini bersumber/ dikutip dari berbagai sumber seperti teks hinggilan, 


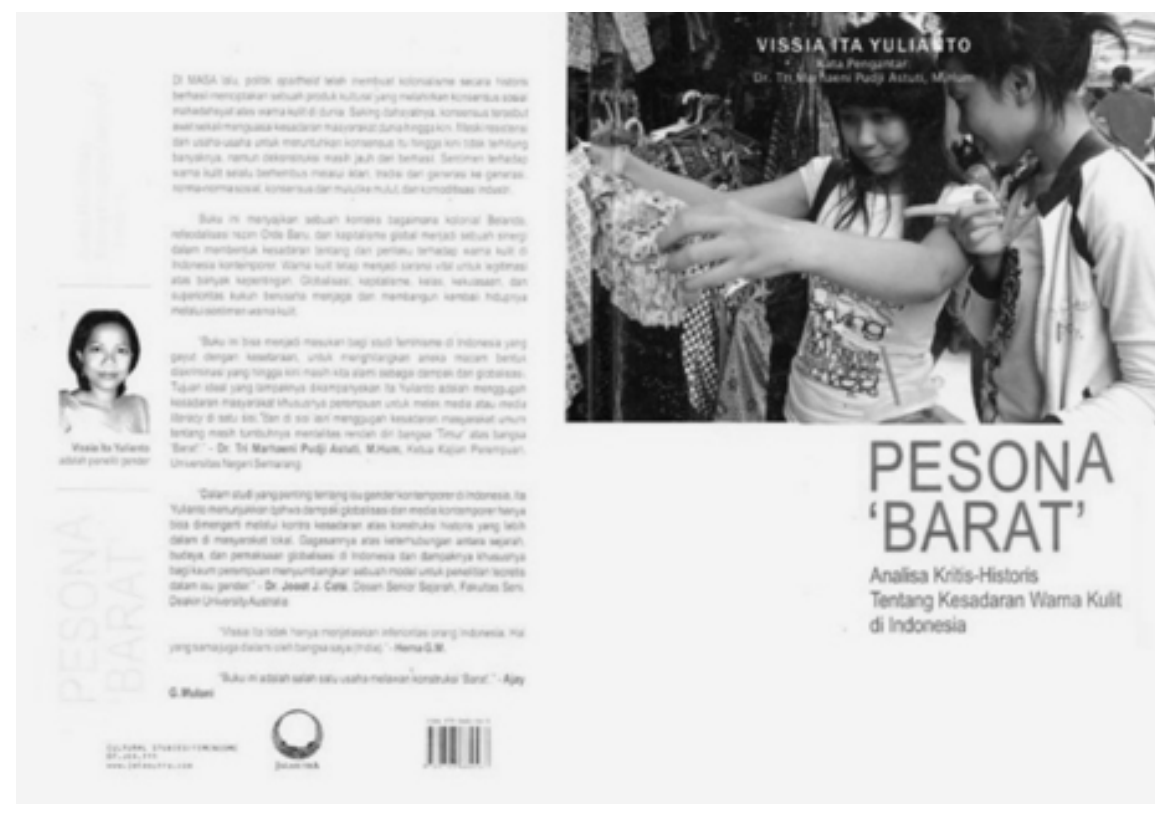

Gambar 7. Sampul buku "Pesona 'Barat'" (Sumber: Widyatmoko)

pernyataan presiden Soekarno, dan konstruksi perempuan masa Orde Baru. Kesadaran tentang warna kulit perempuan pun kerap menjadi perbincangan di berbagai media massa, dari yang pro, kontra, hingga yang belum/ tidak tahu mesti bersikap apa.

Metode visual sampul buku "Pesona Barat" yaitu fotografi. Lokasi foto di pasar Beringharjo, Yogyakarta. Mengapa (di) pasar Beringharjo? Di pasar Beringharjo, maupun di Mirota Batik (toko yang sering dirujuk orangorang guna membeli barang-barang oriental, barang-barang khas Jawa, pakaian hingga mainan) misalkan, kedua tempat tersebut merupakan sebuah ruang di mana etnisitas "diperkenalkan kembali".

Diperkenalkan di sini dalam artian ia dihadirkan lewat berbagai komoditas seperti pakaian, peralatan rumah tangga, ramuan-ramuan, dsb. Sungguh menarik, manakala adegan kita selaku pribumi, sebagai konsumen/ pembeli melihat lihat barang (re)presentasi entisitas tersebut. Kita merasa akrab namun di sisi lain kita merasa asing (mengalami suatu situasi eksotis). Di sinilah yang dimaksud berlangsung mekanisme ambivalensi, yaitu suatu situasi manakala kita terombang ambing antara menjadi ini (terberi) dan (mau) menjadi itu, dan kedua pilihan tersebut sama kuatnya.
Dalam foto sampul "Pesona Barat" ambivalensi tersebut secara tak sadar hadir dalam berbagai objek/narasi antara lain gelas minuman instant, jaket, potongan rambut, hingga yang dikenakan kedua perempuan dalam foto tersebut. objek-objek tersebut merupakan bentuk budaya populer (untuk menunda mengatakan total sebagai representasi budaya Barat, namun dapat untuk mengatakan sebagai budaya yang dibangun oleh media massa). objek-objek bernarasi "being becoming West" tadi dihadapkan pada ruang perjumpaan dengan yang etnis, lokal, yang oriental (Jawa) yaitu melihat lihat pakaian bermotif batik di pasar Beringharjo. Jika jari salah satu perempuan dalam foto sampul tersebut memegang gelas minuman instant sembari tangan yang lain menunjuk-nunjuk pakaian yang dijual, hal ini bisa mengatakan ada suatu prinsip dalam tindakan dalam artian mengalami ambivalensi oleh objek-objek yang selama ini dinilai eksotis yang di satu sisi (justru) merupakan bagian dari (narasi identitas) dirinya. Di sini ambivalensi tak sebatas benci tapi rindu.

Bukankah di pasar berbagai komoditi kerap menyediakan hal hal yang demikian, lantas kita terburu menamainya sebagai praktik kesenangan mengonsumsi. Boleh disampaikan yang berlangsung justru sebaliknya: aku mengonsumsi bukan untuk kesenangan, namun 
memenuhi sebagian identitasku yang selama ini (ter)asingkan. Estetika desain dalam sampul buku 'Pesona Barat' terletak pada wilayah subjek yang ambivalen manakala berjumpa dengan etnisitas dan eksotisme. Sebagai cara menunjukkannya yaitu melalui foto everyday life (humanity), sebagai sebuah komunikasi yang mau menyampaikan realitas sehari-hari. Inilah dasar konsep estetik sampul buku tersebut.

\section{Kesimpulan}

Ulasan tiga karya desain komunikasi visual di atas setidaknya dapat menggambarkan bagaimana kedudukan estetika dalam tiap karya tersebut. Pertama, pada typeface "Nusantara" estetika berada pada soal negisoasi yang lokal dengan yang lokal. Namun, dari kacamata kelokalan, estetika juga dapat dikritik manakala di sana muncul dominasi suatu budaya (yaitu Jawa) untuk mewakili Nusantara. Estetika yang negosiatif kiranya dapat digunakan guna menjelaskan bahwa dalam perancangan desain dengan kasus yang demikian senantiasa makna tidaklah stabil, namun sebagai pilihan merancang tetap harus dikerjakan (partisipasi). Kedua, pada kemasan Wingko Babat estetika dapat dihubungkan dengan pengalaman modern di kota. Pergeseran pusat kota, termasuk somasi yang dilakukan pelopor produsen Wingko Babat, menyebabkan perubahan (gambar) desain-desain kemasan Wingko Babat tersebut. Ketiga, pada sampul buku "Pesona 'Barat"' estetika terkait dengan pengalaman ambivalensi akan entisitas dalam perjumpaan dengan yang global, dan situasi ambivalen tersebut ketika seseorang berada di pasar.

Ketiga kasus tersebut jika dirangkum ke dalam satu wacana estetik yaitu semuanya mengerucut pada persoalan tentang identitas. Kaitan wacana identitas dengan desain komunikasi visual sangat dekat, yaitu desain sebagai penanda jaman, budaya (lokal, nasional, global), hingga yang sehari-hari. Di sinilah konsep estetik sebuah desain tidak berhenti pada yang formal, namun juga terelasikan dengan yang kontekstual, terutama wacana-wacana dalam kebudayaan.

\section{Dafar Pustaka}

Afnita, Natalia, (Budaya) Kemasan Wingko Babat, Jurnal ARS FSR ISI Yogyakarta. 2009.

Desain Kemasan Wingko Babat, Studi Perubahan Desain Kemasan Sejak Awal Kemunculannya Hingga Kini di Semarang (1958-2010). Tugas Akhir Pengkajian Desain Komunikasi Visual ISI Yogyakarta. 2010.

Basundoro, Purnawan, Pengantar Sejarah Kota, Ombak, 2012

Laksana, Prima Ditya, Perancangan Typeface Bercitra Budaya Indonesia. Tugas Akhir Penciptaan Desain Komunikasi Visual ISI Yogyakarta. 2012.

“Empat Esai Etika Politik”.www.srimulyani.net bekerjasama dengan Komunitas Salihara. Februari. 2011. 